\title{
PENERAPAN MODEL PEMBELAJARAN INKUIRI DALAM UPAYA MENINGKATKAN HASIL BELAJAR IPA SISWA KELAS II SD NEGERI O5 KABAWETAN
}

\author{
Nurhaida \\ SD Negeri 5 Kabawetan
}

\begin{abstract}
Abstrak
IPA merupakan pelajaran yang sangat penting dikuasai oleh siswa. Siswa dapat memahami dan dapat meningkatkan hasil belajarnya tergantung dari beberapa faktor salah satunya adalah model pembelajaran yang digunakan oleh guru dalam proses belajar mengajar. Tujuan dari penelitian ini adalah untuk mendeskripsikan bahwa dengan menerapkan model pembelajaran inkuiri dapat meningkatkan hasil belajar siswa. Masalah pokok dalam penelitian ini adalah: 1) Apakah dengan penerapan model pembelajaran inkuiri pada materi Sumber energi dan kegunaannya dapat meningkatkan hasil belajar siswa kelas II SD Negeri 05 Kabawetan? 2) Bagaimana aktivitas siswa kelas II SD Negeri 05 Kabawetan selama diterapkannya model pembelajaran inkuiri? 3) Bagaimana tanggapan siswa kelas II SD Negeri 05 Kabawetan terhadap model pembelajaran inkuiri? Dalam penelitian ini yang menjadi subjek penelitian adalah siswa kelas II SD Negeri 05 Kabawetan tahun ajaran 2015/2016. Instrumen yang digunakan dalam penelitian ini diantaranya : Lembar Kerja siswa (LKS), tes individu, dan angket respon siswa, serta lembar observasi siswa. Berdasarkan hasil penelitian pada siklus I, II dan III terdapat peningkatan hasil belajar siswa dari segi nilai rata - rata adalah 5,5 sedangkan persentase secara klasikal mencapai $20 \%$ siswa yang mendapat nilai $\geq 60$. Aktifitas siswa selama proses pembelajaran juga mengalami peningkatan setiap siklusnya yaitu 20\%, 85.\% dan terakhir meningkat menjadi $90 \%$. Pada umumnya siswa merespon terhadap penerapan model pembelajaran inkuiri. Sebagian besar berpendapat bahwa semangat belajar meningkat, menyenangkan dan menarik, serta hasil belajar meningkat. Dengan demikian model pembelajaran inkuiri dapat dijadikan alternatif dalam menyampaikan materi sumber energi dan kegunaannya karena dapat meningkatkan hasil belajar siswa, bimbingan yang diberikan secara merata terutama pada kelompok yang membutuhkan dapat memotivasi siswa dalam belajar, pengggunaan model pembelajaran yang bervariasi dan menyenangkan dapat membuat siswa nyaman dan senang dalam belajar IPA.
\end{abstract}

Kata Kunci : Inkuiri, Hasil Belajar, IPA, Siswa Kelas II

\section{PENDAHULUAN}

Peran guru dalam pembelajaran tidak hanya sebagai pusat dan penyampai informasi saja akan tetapi sebagai fasilitator, motivator dan pembimbing yang memberikan kesempatan kepada siswa untuk menemukan sendiri pembelajaran dan pengembangan pola pikir dalam pembelajaran. Para siswa diharapkan kritis terhadap permasalahan yang terjadi di lingkungan sekitarnya, terutama dalam mata pelajaran Ilmu
Pengetahuan Alam (IPA) yang senantiasa berhubungan dengan alam sekitar.

Berdasarkan hasil temuan peneliti di kelas II SD Negeri 05 Kabawetan Kabupaten Kepahiang yang merupakan tempat penulis bertugas sebagai guru. Permasalahan yang kerap muncul pada pembelajaran IPA di kelas yaitu siswa kurang bersemangat dalam mengikuti pelajaran. Hal ini timbul karena beberapa faktor.

Diantaranya sarana dan prasarana termasuk sumber belajar di sekolah belum memadai dan siswa masih terlihat malu - malu ketika 
dilibatkan dalam kegiatan belajar mengajar. Disamping itu sebagian siswa ada yang mengalami kesulitan dalam membaca sehingga substansi dari materi pelajaran kurang maksimal tersampaikan. Selain itu belum ditemukan model pembelajaran yang cocok untuk mengatasi permasalahan tersebut. Faktor - faktor tersebutlah yang turut berpengaruh terhadap hasil belajar siswa yang belum memuaskan.

$$
\text { Ketepatan dalam memilih model }
$$

pembelajaran akan berpengaruh baik terhadap hasil belajar siswa. Salah satu model pembelajaran yang cocok dengan mata pelajaran IPA adalah model pembelajaran inkuiri.

Menurut Ilah (2012:97), inkuiri adalah salah satu cara untuk mengatasi masalah kebosanan siswa dalam belajar di kelas karena proses belajar lebih terpusat pada siswa dari pada guru. Inkuiri merupakan suatu perluasan proses discovery yang mengandung proses- proses mental yang lebih tinggi tingkatannya. Misalnya merumuskan problem, merancang eksperimen, melakukan eksperimen, mengumpulkan dan menganalisis data menarik kesimpulan, mempunyai sikap-sikap objektif, jujur, hasrat ingin tahu, terbuka dan sebagainya.Inkuiri adalah salah satu cara untuk mengatasi masalah kebosanan siswa dalam belajar di kelas karena proses belajar lebih terpusat pada siswa dari pada guru. Inkuiri merupakan suatu perluasan proses discovery yang mengandung proses- proses mental yang lebih tinggi tingkatannya. Misalnya merumuskan problem, merancang eksperimen, melakukan eksperimen, mengumpulkan dan menganalisis data menarik kesimpulan, mempunyai sikap-sikap objektif, jujur, hasrat ingin tahu, terbuka dan sebagainya.

Model pembelajaran inkuid dapat dikatakan sebagai model pembelajaran partisipatif karena melibatkan partisipasi siswa dalam pembelajaran. Siswa akan mengalami, menghayati dan menarik pelajaran dari pengalaman itu, sehingga hasil belajar akan menjadi bagian dari dirinya. Hasil belajar akan lebih lestari, disamping tentu saja kreativitas siswa dibina dan dikembangkan.
Dari masalah di atas, maka penulis tertarik untuk melakukan Penelitian Tindakan Kelas dengan judul "Upaya meningkatkan hasil belajar IPA melalui Penerapan Model Pembelajaran Inkuiri Siswa Kelas II SD Negeri 05 Kabawetan".

Penelitian Tindakan Kelas ini dilakukan pada Materi Sumber Energi dan Kegunaannya dalam Mata pelajaran IPA.

\section{METODE}

Penelitian ini merupakan teknik penelitian tindakan kelas (Classroom Action Research). Penelitian tindakan kelas adalah suatu bentuk penelitian yang bersifat reflektif dengan menggunakan tindakan agar dapat memperbaiki pembelajaran di kelas (Kasbuloh,1999:4). Penelitian tindakan kelas adalah penelitian tindakan dalam bidang pendidikan yang melaksanakannya di dalam kelas dengan tujuan untuk memperbaiki dan meningkatkan kualitas pembelajaran.

Dalam pelaksanaan penelitian tindakan kelas ini dimulai rencana tindakan, observasi dan refleksi, merupakan tahapan yang saling berhubungan antara yang satu dengan yang lainnya. Pada masing-masing tahapan meliputi proses penyempurnaan yang didasarkan atas hasil dari masing-masing proses. Dimulai dari rencana lalu diadakan tindakan dan observasi kemudian diadakan refleksi.

Penelitian Tindakan Kelas ini dilaksanakan di SD Negeri 05 Kabawetan pada mata pelajaran IPA dengan materi Sumber Energi dan Kegunaannya. Sebagai subjek dalam penelitian ini adalah siswa - siswi kelas II tahun pelajaran 2015/2016 dengan jumlah siswa 20 orang, terdiri dari 8 orang laki - laki dan 12 orang perempuan

Instrumen adalah sarana penelitian (berupa tes dan nontes) untuk memperoleh data dalam kegiatan pengumpulan, pengolahan, analisis, dan penyajian data. Instrumen penelitian yang digunakan dalarn kegiatan penelitian tindak kelas ini adalah dua jenis yaitu instumen pembelajaran dan instumen pengumpulan data. 
Instrumen pembelajaran yang digunakan dalam penilaian tindakan kelas ini, yaitu: Rencana Pelaksanaan Pembelajaran (RPP), Lembar Kerja Siswa (LKS), dan tes individu.

Instrumen Pengumpulan data dalam penelitian tindakan kelas ini yaitu menggunakan tes dan nontes. Teknik pengumpulan data dalam penelitian ini adalah pelaksanaan tes, observasi, wawancara, diskusi kelompok, dan pengisian angket.

\section{HASIL}

\section{Siklus I}

Pada tahap perencanaan (planning), ada beberapa hal yang dilakukan yaitu: menentukan pokok bahasan yang akan diajarkan yaitu sumber energi dan kegunaannya, merancang Rencana Pelaksanaan Pembelajaran model pembelajaran inkuiri sebagai pedoman dalam kegiatan belajar mengajar untuk materi sumber energi dan kegunaannya pada indikator :

1. Menyebutkan sumber energi bunyi,

2. Mencari sumber bunyi melalui alat rumah tangga, merancang latihan soal / LKS yang akan diselesaikan secara berkelompok beserta merancang soal untuk tes individu, menyiapkan lembar observasi untuk siswa dan membagi siswa dalam 5 kelompok yang masingmasing terdiri dari 4 orang.

Tahap pelaksanaan (acting) pada siklus I diantaranya mengabsen siswa terlebih dahulu kemudian membagi siswa dalam 5 kelompok yang masing-masing terdiri atas 4 orang. Peneliti menjelaskan tentang model pembelajaran yang akan dipakai selama pembelajaran yaitu model pembelajaran inkuiri dan menjelaskan tentang keterampilan-keterampilan yang harus dimiliki selama diterapkannya model pembelajaran inkuiri. Kemudian peneliti menyajikan materi pelajaran yaitu tentang sumber energi dan kegunaannya melalui tanya jawab yang dapat merangsang keingintahuan siswa.

Setelah itu dilanjutkan dengan kegiatan kelompok selama 20 menit, dalam diskusi kelompok peneliti mengarahkan kelompok agar ada pembagian tugas dan kerja sama yang baik dalam menyelesaikan materi diskusi. Dikarenakan ini yang pertama kali, siswa terlihat belum begitu kompak, terutama dalam pembagian tugas. Ada satu kelompok yang anggotanya masih diam dan tidak melakukan apa-apa, yakni kelompok Semangka Akan tetapi guru (peneliti) terus mengarahkan sehingga siswa dapat bekerja dalam kelompok. Setelah selesai belajar kelompok, hasil kerja kelompok dikumpulkan.

Setelah itu peneliti memberikan beberapa pertanyaan untuk memastikan masing-masing kelompok telah memahami pelajaran yang disampaikan, kemudian penguatan dan kesimpulan secara bersama - sama dan terakhir mengerjakan tes secara individu.

Tahap pengamatan (observing), ketika kegiatan belajar mengajar peneliti juga melakukan pengamatan terhadap aktivitas siswa selama proses belajar mengajar. Selanjutnya peneliti melakukan penelitian hasil pekerjaan siswa dalam kerja kelompok / diskusi dan hasil belajar siswa dalam tes yang diberikan untuk penilaian secara individual.

Tahap refleksi (reflecting ) dari siklus I, peneliti merasa ada kelemahan yang harus diperbaiki untuk melakukan tindakan di siklus II. Pada siklus II kelompok belajar siswa akan diubah, akan tetapi masih dalam komposisi yang heterogen.

Dari beberapa tahap yang dilakukan pada siklus I semua data seperti lembar oservasi dan hasil belajar siswa dianalisis. Adapun hasil analisisnya sebagai berikut:

a. Dalam diskusi kelompok hampir semua kelompok sudah bisa melaksanakan tugas dengan baik serta adanya kerja sama. Akan tetapi ada satu kelompok yang kurang kompak dan salah satu anggotanya diam, yaitu kelompok Semangka.

b. Dari jumlah siswa yang hadir, pada pelajaran itu menghasilkan data sebagai 
berikut sebanyak 20 orang siswa yang memperoleh nilai di bawah 60 dan 4 orang siswa memperoleh nilai $>60$, rata rata kelas diperoleh 5,5 dan presentase secara klasikal siswa yang memperoleh nilai $\geq 60$ adalah $20 \%$.

\section{Siklus II}

Siklus II dilaksanakan pada hari Selasa tanggal 7 April 2015 dan hari Selasa tanggal 14 April 2015.Pada tahap perencanaan (planning ) dilakukan langkah - langkah sebagai berikut

a. Merancang dan menyusun Rencana

Pelaksanaan Pembelajaran untuk materi sumber energi dan kegunaannya (lanjutan) dengan indikator :

1) Menyebutkan benda yang menggunakan listrik,

2) Menjelaskan penggunaan energy listrik, menyusun lembar kerja siswa untuk diskusi kelompok, menyusun dan menyiapkan lembar observasi pembelajaran untuk siswa.

Tahap pelaksanaan (acting) yaitu melaksanakan kegiatan belajar mengajar sesuai rencnna pembelajaran yang telah dibuat, dengan melakukan presensi dan memberikan instruksi agar siswa duduk secara berkelompok. Kemudian apersepsi dan menyajikan materi pelajaran dengan tanyajawab yang merangsang siswa yaitu melanjutkan materi tentang sumber energi dan kegunaannya. Setelah itu kegiatan diskusi kelompok selama 20 menit dengan diberikan lembar kerja siswa (LKS) untuk diskusi, dalam diskusi peneliti mengarahkan dan membantu siswa yang mengalami kesulitan.

Setelah selesai diskusi kelompok tugas kelompok dikumpulkan kemudian peneliti memberikan pertanyaan untuk memastikan apakah siswa sudah memahami materi pelajaran atau belum. Selanjutnya siswa diberikan kesempatan untuk memberikan tanggapan dan pertanyaan. Kemudian memberikan penguatan dan kesimpulan secara bersama - sama dan terakhir memberikan tes individu kedua.
Tahap pengamatan (observing), pada siklus II peneliti juga melakukan pengamatan terhadap aktivitas kegiatan siswa selama pembelajaran berlangsung.

Tahap refleksi (reflecting), hasil penelitian dari beberapa pertanyaan yang diberikan secara berkelompok dan dari soal tess yang dikerjakan siswa serta dari pengamatan peneliti diperoleh data sebagai berikut $100 \%$ siswa yang hadir cukup aktif, semua kelompok sudah aktif dalam diskusi, siswa berani bertanya dan siswa yang lain menjawab pertanyaan dengan baik dan benar, semakin bertambah siswa yang berani maju ke depan kelas untuk menyelesaikan soal.

Dari 20 siswa yang hadir, menghasilkan data sebagai berikut:

1) Sebanyak 16 orang siswa memperoleh nilai di bawah 70 dan 4 orang siswa memperoleh nilai $\geq 60$;

2) Rata - rata kelas diperoleh 55

3) Persentase siswa yang memproleh nilai minimal 60 adalah $80 \%$.

Dengan demikian target peneliti untuk rata - rata kelas dan persentase klasikal nilai siswa 60 belum tercapai. Diperoleh kesimpulan bahwa siswa belum benar - benar memahami materi pelajaran khususnya pada materi di siklus II. Hal ini terjadi karena waktu yang diberikan untuk diskusi kelompok tidak culup dengan durasi 20 menit untuk materi sehingga siswa yang belum paham, ada yang belum sempat bertanya kepada teman di kelompoknya. Untuk itu di siklus III waktu disesuaikan dengan materi dan untuk meningkatkan hasil belajar, kelompok belajar kembali dirubah.

\section{Siklus III}

Siklus III ini dilaksanakan 2 kali pertemuan ( 4 jam pelajaran ), yaitu hari Selasa tanggal 19 Mei 2015 dan hari Rabu tanggal 20 Mei 2015.

Tahap perencanaan (planning), langkahlangkahnya meliputi: merancang dan menyusun 
Rencana Pelaksanaan Pembelajaran mengenai materi lanjutan sumber energi dan kegunaannya pada indikator :

1) Menyebutkan benda - benda yang ada di rumah yang menggunakan energi listrik,

2) Menjelaskan alas an menghemat energi listrik

3) Memberikan contoh cara menghemat energi listrik, menyusun alat evaluasi dalam bentuk Lembar Kerja Siswa untuk diskusi kelompok, menyusun soal tes individu, menyusun dan menyiapkan lembar observasi, angket tanggapan siswa terhadap model pembelajaran inkuiri.

Pada tahap pelaksanaal (acting), peneliti melaksanakan kegiatan belajar mengajar sesuai dengan Rencana Pelaksanaan Pembelajaran yang telah dibuat, yaitu presensi dan pengkondisian siswa agar duduk secara berkelompok. Kemudian menyajikan materi pelajaran, kegiatan diskusi kelompok selama 20 menit dengan diberikan LKS untuk diskusi, dalam diskusi peneliti hanya memantau tidak banyak mengarahkan karena siswa sudah kompak dalam bekerja sama.

Setelah kerja kelompok selesai, hasilnya dikumpulkan selanjutnya peneliti memberikan pertanyaan untuk memastikan apakah siswa sudah memahami materi atau belum. Dari beberapa pertanyaan yang diberikan, banyak siswa yang mengacungkan jari ingin menjawab. Kemudian penguatan materi dan penarikan kesimpulan secara bersama-sama dan terakhir siswa diberikan tes individu III dan pengisian angket respon siswa terhadap model pembelajaran inkuiri.

Tahap pengamatan (observing), dalam tahap ini peneliti kembali mengamati dan mengevaluasi proses pembelajaran terutama keaktifan dan cara kerja siswa dalam kelompoknya. Pada Siklus III peneliti melakukan penilaian hasil kerja siswa dari tes yang diberikan untuk penilaian secara individual.

Dari hasil pengamatan selama pembelajaran di kelas, selanjutnya diadakan refleksi (reflecting) atas segala kegiatan yang dilakukan pada Siklus III. Kegiatan pembelajaran berjalan dengan lancar karena siswa sudah terbiasa dengan teman kelompoknya, sudah $100 \%$ siswa aktif dalam kegiatan belajar mengajar, siswa tidak lagi mengandalkan bimbingan peneliti, siswa yang berani maju ke depan semakin bertambah banyak. Adapun hasil yang diperoleh dari siswa, sebagai berikut:

1) Sebanyak 20 orang siswa memperoleh nilai di bawah 3 dan 17 orang siswa memperoleh nilai $\geq 60$;

2) Rata-rata kelas diperoleh 79.

3) Persentase siswa yang memproleh nilai minimal 60 adalah $85 \%$.

Berdasarkan data yang diperoleh dari hasil tes pada Siklus I sampai Siklus III mengalami peningkatan dari segi nilai berdasarkan Kriteria Ketuntasan Minimal ( KKM ) di SD Negeri 09 Kepahiang untuk materi sumber energi dan kegunaannya. Makin banyak siswa yang telah tuntas belajarnya untuk materi tersebut sehingga dapat dikatakan bahwa pelaksanaan penelitian Tindakan Kelas ini telah selesai dan berhasil dengan baik. Perkembangan nilai rata - rata dan perkembangan aktivitas siswa siklus I, II, dan III sebagai berikut : Siklus I nilai rata-rata 55, siklus II nilai rata-rata 79 , dan sikus III nilai rata-rata 97.

\section{PEMBAHASAN}

Pembahasan yang diuraikan di sini didasarkan pada hasil dari hasil pengamatan, nilai tes, serta hasil dari penyebaran angket pada akhir siklus penelitian yang diteruskan dengan kegiatan refleksi. Berdasarkan hasil refleksi, pada siklus I, dihasilkan antara lain masih ada kelompok diskusi yang belum kompak dan belum bisa bekerja sama dengan baik, yaitu kelompok Semangka sehingga ada salah satu dari anggota kelompok tersebut yang diam dan hanya melihat temannya saja. Hasil nilai kuis pada siklus I belum memenuhi target hanya memperoleh nilai rata - rata 5,5 dan secara klasikal siswa yang 
memperoleh nilai 60 ke atas 20\%, belum memenuhi target peneliti.

Pada siklus II, hampir semua kelompok diskusi sudah bisa bekerja sama dengan baik tidak ada lagi siswa yang diam. Aktivitas siswa dalam kegiatan belajar mengajar lebih meningkat, dilihat dari keberanian siswa dalam menjawab pertanyaan dan makin banyak siswa yang berani maju ke depan kelas untuk mengerjakan soal yang diberikan oleh peneliti. Akan tetapi dari hasil tes individu nilai rata - rata hanya 7,9 dan secara klasikal siswa yang memperoleh nilai 60 ke atas hanya $85 \%$. Setelah diteliti dengan seksama, hal ini disebabkan materi yang dipelajari dianggap sulit oleh siswa. Dari data tersebut, target peneliti belum tercapai dari segi nilai akademik. Akan tetapi dari segi keaktifan siswa sudah tercapai.

Dalam siklus III, dari segi aktivitas siswa dalam belajar lebih meningkat dibandingkan pada siklus II. Siswa sudah tidak diarahkan lagi dalam diskusi kelompok dan setiap ketua kelompok sudah terbiasa membagi tugas kepada anggotanya. 90\% siswa sudah aktif dalam kegiatan belajar mengajar. Untuk nilai rata- rata sudah memenuhi target yaitu dengan nilai 60 dan secara klasikal siswa yang mendapat nilai $\geq 60$ sudah mencapai $100 \%$.

Berdasarkan data tentang hasil belajar siswa selama proses penelitian pada siklus I, II, dan III yang diperoleh dari hasil kerja kelompok dan tes, maka dapat dikatakan bahwa proses pembelajaran telah selesai dan berhasil dengan rata - rata diperoleh 9,7 dan secara klasikal siswa yang memperoleh nilai $\geq 60$ mencapai $100 \%$.

Dari hasil penyebaran angket diperoleh data : 70\% dari seluruh siswa yang berpendapat bahwa dengan model pembelajaran inkuiri dapat membuat mereka semangat dalam belajar $72 \%$ berpendapat model pembelajaran inkuiri merupakan model pembelajaran yang menyenangkan dan menarik. Sebanyak $85 \%$ siswa berpendapat bahwa dengan model pembelajaran inkuiri hasil belajar mereka meningkat.

\section{SIMPULAN}

Dari seluruh kegiatan Penelitian Tindakan Kelas di kelas II SD Negeri 05 Kabawetan Kabupaten Kepahiang disimpulkan bahwa dengan menerapkan model pembelajaran inkuiri pada materi sumber energi dan kegunaannya dapat meningkatkan hasil belajar siswa yang dilihat dari ketuntasan siswa dalam belajar meningkat pada siklus III mencapai $77 \%$ dan berhasil meningkatkan aktivitas siswa dalam kegiatan belajar mengajar dengan persentase tiap siklus $55 \%, 79 \%$ dan $97 \%$.

Selain itu sebagian besar siswa berpendapat bahwa dengan model pembelajaran inkuiri dapat membuat mereka semangat dalam belajar, model pembelajaran inkuiri merupakan model pembelajaran yang menyenangkan dan menarik serta dengan model pembelajaran inkuiri hasil belajar mereka meningkat.

\section{SARAN}

Berdasarkan pengalarnan selama melaksanakan Penelitian Tindakan Kelas di kelas II SD Negeri 05 Kabawetan, maka hal yang dapat peneliti sarankan sebagai berikut:

1. Model pembelajaran inkuiri dapat dijadikan alternatif dalarn menyampaikan materi sumber energi dan kegunaannya karena dapat meningkatkan hasil belajar siswa;

2. Bimbingan yang diberikan secara merata terutama pada kelompok yang membutuhkan dapat memotivasi siswa dalarn belajar;

3. Pengggunaan model pembelajaran yang bervariasi dan menyenangkan dapat membuat siswa nyaman dan senang dalam belajar IPA. 


\section{DAFTAR PUSTAKA}

Ali, M. 2002. Guru dalam Proses Belajar Mengajar. Bandung: Sinar Baru Algesindo Offset.

Dimyati dan Mujiono . 1999. Belajar dan Pembelajaran. Jakarta: Rineka Cipta.

Gulo,W. 2002. Strategi Belajar - Mengajar. Jakarta :.PT. Grasindo

Kasbuloh, Kasihani. 1999. Penelitian Tindakan Kelas (PTK).Malang :Depdikbud.

Kunandar.2008. Langkah Mudah Penelitian Kelas sebagai pengembangan Profesi Guru.Jakarta : PT. Raja Grafindo Pemada.
Moleong Lexy,J.2004. Metode Penelitian Kualitatif. Bandung :Remaja Rosdakarya

Munandar, Utami. 1992. Mengembangkan Bakat dan Kreativitas anak Sekolah. Jakarta. PT Gramedia Widia Sarana Indonesia

Sudjana Nana. 2005. Penilaian Hasil Proses Belajar Mengajar. Bandung: PT. Remaja Rosdakarya.

Syaeful Anwar, CucuSuhendar (2008), IlmuPengetahuan IPA SD/MI Kls II. Jakarta: PusatPerbukuanDepdiknas

Rusyan, A.T. 2003. Pedoman Mengajar IPA Untuk Sekolah Dasar. Jakarta: Intimedia Cipta Nusantara.

Kurikulum SD Negeri 05 Kabawetan. 